\title{
Production and Productivity of Pulses in India: Role of Combined Quality Inputs Usage
}

\author{
Jayanta Sen $^{1 *}$, Sreetama Bhattacharjee ${ }^{2}$ and Debarati Das ${ }^{1}$ \\ ${ }^{1}$ Department of Economics, West Bengal State University, Kolkata-700126, West Bengal, India \\ ${ }^{2}$ Department of Agriculture and Rural Development, West Bengal State University, Kolkata-700126, West Bengal, India \\ *Correspondence author: senj123@gmail.com
}

\begin{abstract}
Pulses are the predominant and cheaper source of protein to the majority of people in India especially who are poor and unable to access high priced animal protein. Though our country is the largest producer and importer of pulses, the economy has failed to meet the rising domestic demand recently. Price of pulses has increased enormously in recent years and it has become beyond the reach of the poor. In this context interest grows to explore the supply side of pulses in India after economic reforms. An attempt has been made in this paper to examine the changing pattern of production and yield of pulses across Indian states. Contributions of different states to the production of different types of pulses are examined. Eventually factors affecting pulse production in India and their relative roles are examined. Composite quality Input Index (CII), net availability of under-ground water, and proportion of indebted farmers are some of the factors that significantly affect per hectare pulse production in India.
\end{abstract}

Keywords: Pulse production, Yield, Inputs, Determinants

Pulses are the major source of protein, vitamins and minerals for the majority of population in India. These are also considered as the cheaper source of protein to the people of our country especially the poorer sections who are unable to receive the nutrients from high priced food commodities (Joshi and Saxena, 2002). Moreover, people who are vegetarians are enormously dependent on pulses for their protein intake. Domestic demand for pulses is very high from the huge population of our country. Production of pulses has no doubt increased in India, but it has failed to meet the rising domestic demand. Net per capita availability of pulses (per annum) has declined sharply from 60.71 Metric Ton in 1951 to 41.9 Metric Ton in 2013. High domestic demand for pulses has also raised the import propensity which results in outflow of huge amount of foreign reserves (Fig. 1). India stands the first rank among the major pulse importing countries of the world in 2015 (Comtrade, United Nations).

Still the economy has failed to meet the rising domestic demand for pulses and as a consequence, prices have increased enormously in the recent era. The recent price hike of pulses has made consumption of pulses with rice beyond the reach of the poorer sections of our economy. In this context interest thus grows to explore the pattern of production and yield of pulses in India after economic reforms.

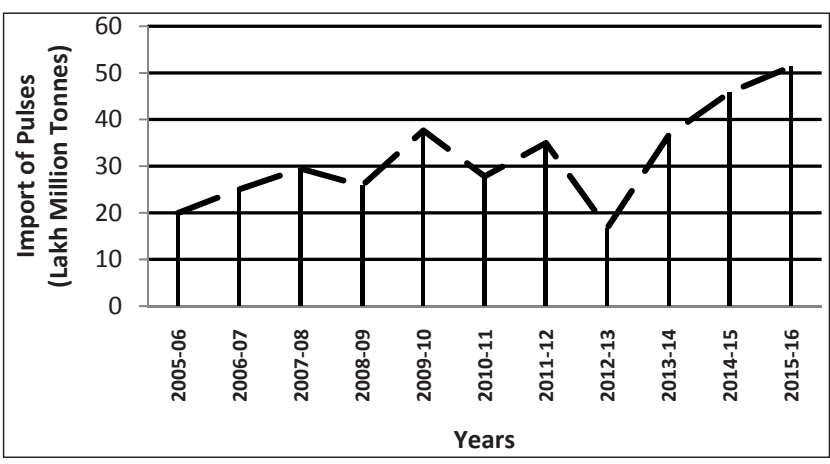

Fig. 1: Import of Pulses by India: 2005-2016

Source: Indian Pulses and Grains Association 
Various research works had dealt with different aspects of pulses (Singh et al. 1993; Roy Burman, et al. 2008; Reddy, 2009; Reddy and Reddy, 2010; Srivastava, et al. 2011; Kumar and Bourai, 2012; Singh, et al. 2013; Ali, et al. 2012; Narayan and Kumar, 2015). Ali and Gupta (2012) in their study focused on supply of pulses in India. They emphasized on the requirement of technology drivers for raising pulse production. Reddy (2009) argued on technological efforts need to be supported by the appropriate policy environment which would boost research and development in agriculture. Several studies have highlighted the projection of the future demand for pulse in India (Mittal, 2006; Kumar, 1998). Almost all the studies are aggregate analysis of pulse production in India. But in this paper, we have tried to perform a disaggregative analysis by considering various types of pulses, such as, Chickpea (Gram), Pigeonpea (Arhar/ Tur), Urdbean (Urad), Mungbean (Moong), and Lentil (Masoor). An attempt has been made in this paper to examine the changing pattern of production and productivity of different types of pulses both over space and over time. Role of several explaining factors affecting pulse production in India is judged explicitly. Apart from geographical and ecological factors, role of a composition of quality inputs to the yield of pulses in India is examined by using econometric models.

\section{Data base and Methodology}

The study focuses on the pattern of production of different types of pulses in India and their temporal change over the period 2001 to 2011. Data are collected from Indian Agriculture Statistics at a Glance, Directorate of Economics and Statistics, Agriculture Census, Department of Agriculture and Cooperation, Seed Department, Government of India etc. Two time points are considered in the analysis, i.e. 2001 and 2011.

Contribution (percentage) of each type of pulses to overall pulse production in India and its temporal change has been examined. The contribution of $\mathrm{k}^{\text {th }}$ type of pulse to overall pulse production $\left(\mathrm{CP}_{\mathrm{k}}\right)$ can be expressed as,

$$
\mathrm{CP}_{\mathrm{k}}=\frac{P_{k}}{P} \times 100
$$

Where $P_{k}=$ Production of $\mathrm{k}^{\text {th }}$ type of pulse and
$P=$ Total Production of Pulses

Contribution of each state ( $\mathrm{i}^{\text {th }}$ state) to overall pulse production $\left(\mathrm{CP}_{\mathrm{i}}\right)$ across different types of pulses is also judged. The share of the $\mathrm{i}^{\text {th }}$ state (percentage) for the $\mathrm{k}^{\text {th }}$ type of pulse is,

$$
\mathrm{CP}_{\mathrm{ki}}=\frac{P_{K i}}{P_{k}} \times 100
$$

Where, $P_{k i}=$ production of $\mathrm{k}^{\text {th }}$ type of pulses in the $\mathrm{i}^{\text {th }}$ state.

Changes in the contribution of each state over time have also been analyzed during the period under consideration. Production per hectare or yield of pulses and their over time changes (2010 to 2011) have been studied across states.

Role of composite quality inputs towards better yield of pulses is statistically examined. In order to determine the factors affecting the yield of pulses in India, the following cross-section regression models have been performed, considering thirteen major states of India. Regression models are estimated through Ordinary Least Square (OLS) technique. Regression models are:

$$
\begin{aligned}
Y_{p}= & a_{0}+a_{1} C I I+a_{2} I X I D F A+v_{1} \\
Y_{p}= & a_{0}+a_{1} C I I+a_{2} I X I D F A+a_{3} I X N G W A+\varepsilon_{1} \ldots \\
Y_{p}= & a_{0}+a_{1} C I I+a_{2} I X I D F A+a_{3} I X N G W A+ \\
& a_{4} I X E L C A+w_{1}
\end{aligned}
$$

Where,

$\mathrm{Y}_{\mathrm{p}}$ : Production of Pulses per hectare or Yield of Pulses

CII : Composite Quality Input Index (CII)

IXIDFA : Index of Proportion of Indebted Farmers in Agriculture

IXNWGA : Index of Net Groundwater Availability IXELCA : Index of Share of Electricity Consumption in Agriculture

We have followed United Nations Development Programme (UNDP) methodology of Human Development Index (HDI) in order to compute the index of each variable. The Index (attainment) of each variable $(\mathrm{kth})$ is defined as:

$$
I X_{k}=\frac{\begin{array}{c}
\text { (Actual Value of } k- \\
\text { Minimum Value of } k \text { ) }
\end{array}}{\begin{array}{c}
\text { (Maximum Value of } k- \\
\text { Minimum Value of } k \text { ) }
\end{array}}
$$


Maximum and minimum values of the variable concerned are chosen from the ranking of the states. One of the major objectives of making index is to consider the normalized value of the variables.

Composite Quality Input Index (CII) has been formulated by using five indicators. All indicators are transformed into index form by following the UNDP methodology as mentioned above. The CII is the average of the following five indices:

- Index of irrigated area as a percentage of total gross cropped area (GCA) of pulses (IXAI)

- Index of area treated with chemical fertilizer as a percentage of total gross cropped area (GCA) of pulses (IXATCF)

- Index of area treated with Farm Yard Manure as a percentage of total gross cropped area (GCA) of pulses (IXATFYM)

- Index of area treated with pesticides as a percentage of total gross cropped area (GCA) of pulses (IXATP)

- Area treated with HYV seeds to total gross cropped area (GCA) of pulses (\%) (IXATHYV)

We have considered above mentioned models by combining different explanatory variables (apart from CII) to check the robustness of the influence of CII towards pulse production in India.

\section{RESULTS AND DISCUSSION}

Production of pulses (in aggregate) in India has increased steadily during the period 1951 to 2013 (Fig. 2).

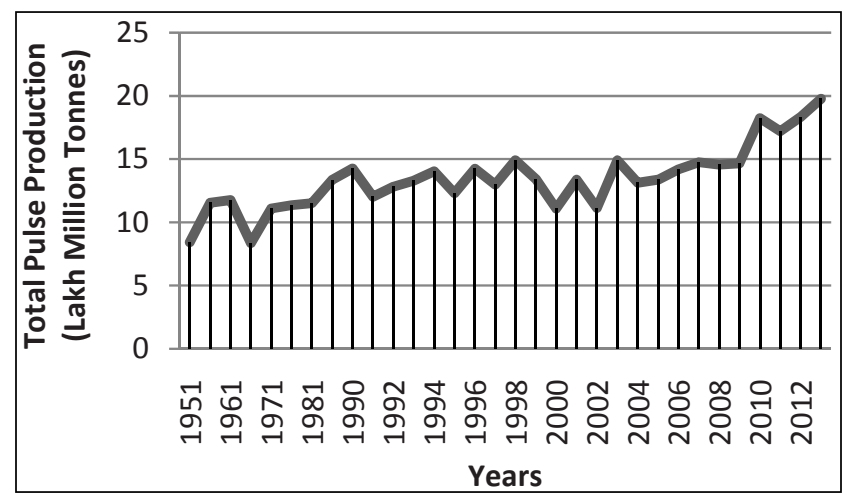

Fig. 2: Trend of Pulse Production in India

Source: Agriculture 2014 at a Glance

Although the production pattern exhibited almost steady in the 1990s, an increasing trend was observed after 2008. The production of pulses varies across major Indian states. Some states are highly pronounced, some states are less. Pulse production in India is concentrated in few states like Madhya Pradesh, Maharashtra, Rajasthan and Uttar Pradesh (Fig. 3 and 4).

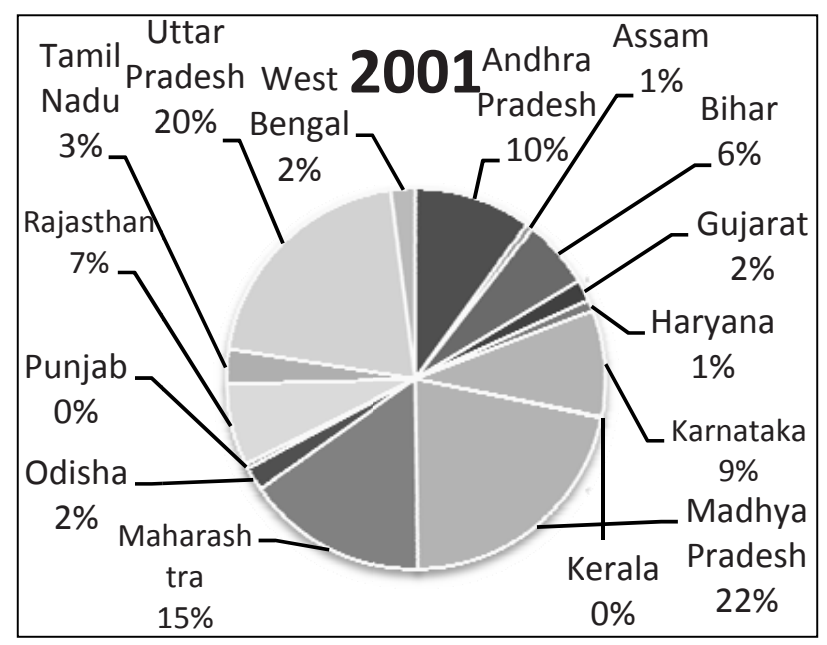

Fig. 3: Contribution of each state to the overall Pulse Production in 2001

Source: Calculated from Agriculture Census

Rajasthan has recorded the highest increase in its share during the period. Percentage share of Uttar Pradesh has declined. No substantial changes are observed in case of shares of other states.

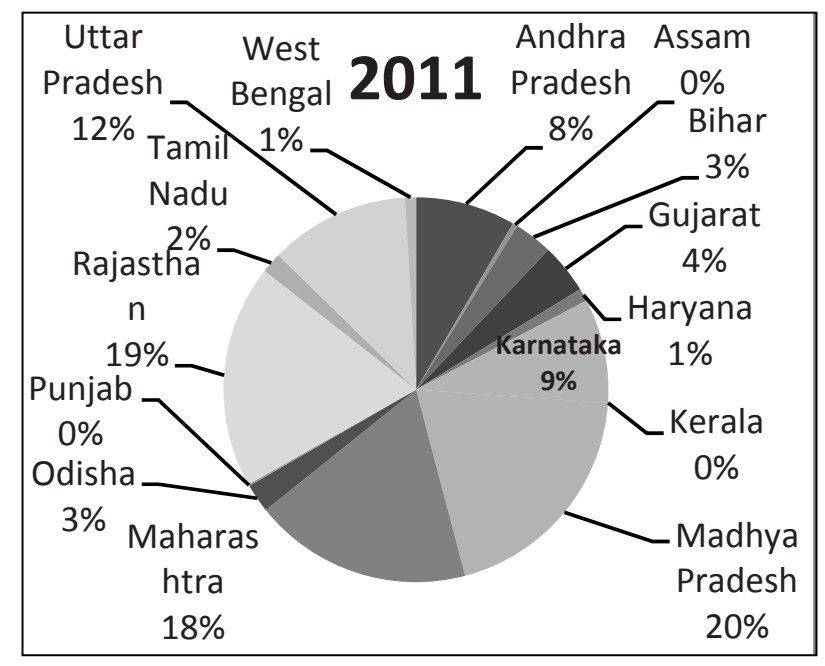

Fig. 4: Contribution of each state to the overall Pulse Production in 2011

Source: Calculated from Agriculture Census Source: Calculated from Agriculture Census

\section{Production of Different Types of Pulses: Indian States}

Different types of pulses like chickpea, pigeonpea, urdbean, mungbean, lentil, etc. are produced in 
India. If we look at the contribution of $\mathrm{k}^{\text {th }}$ type of pulse to overall pulse production $\left(\mathrm{CP}_{\mathrm{K}}\right)$ in India, it is chickpea which shows the highest position followed by pigeonpea, urdbean and other types of pulses in India (Table 1). Share of chickpea production has increased from 35 percent to 45 percent during the period. Share of mungbean has marginally increased.

Table 1: Contribution of $k^{\text {th }}$ type of pulses in overall production in India (\%)

\begin{tabular}{ccc}
\hline \multirow{2}{*}{ Types of Pulses } & \multicolumn{2}{c}{$\mathbf{C P}_{\mathbf{k}}$} \\
\cline { 2 - 3 } & $\mathbf{2 0 0 1}$ & $\mathbf{2 0 1 1}$ \\
\hline Chickpea & 34.84 & 45.07 \\
Pigeonpea & 20.31 & 15.68 \\
Urdbean & 11.64 & 9.65 \\
Mungbean & 9.3 & 9.87 \\
Lentil & 8.3 & 5.15 \\
Other Pulses & 15.61 & 14.18 \\
\hline
\end{tabular}

Source: Author's Calculation

The production share of each type of pulses across major Indian states is depicted in Table 2. The most important pulse crop grown in India is chickpea and highest production share is observed in
Madhya Pradesh (33.78\%) followed by Rajasthan, Maharashtra, and Andhra Pradesh in the year 2011.

Maharashtra and Rajasthan exhibit a substantial decline in the share of chickpea production. Maharashtra is the largest producer of pigeonpea (Tur), accounting for over $31.84 \%$ of total production in the country followed by Karnataka, Madhya Pradesh and Uttar Pradesh. The share of Uttar Pradesh in pigeonpea production has declined steadily while Karnataka and Madhya Pradesh have shown a substantial increase. Urdbean production in the country is concentrated in five states namely, Uttar Pradesh (UP), Maharashtra, Madhya Pradesh, Andhra Pradesh and Tamil Nadu. A sharp decline in the share of Andhra Pradesh is observed during the period. Uttar Pradesh has become the largest contributor in 2011. Maharashtra, Andhra Pradesh and Karnataka were major mungbean producing states in 2001. However, significant rise in production by Rajasthan make it the largest mungbean producing state in 2011. Maximum lentil production comes from Uttar Pradesh (almost 95 percent), followed by Bihar, and Madhya Pradesh. The southern part of the country hardly contributes to India's total lentil production. No substantial change is observed in the shares of lentil production during the period.

Table 2: Percentage Contribution of Indian States towards Production of Pulses: 2001, 2011

\begin{tabular}{|c|c|c|c|c|c|c|c|c|c|c|}
\hline \multirow{3}{*}{ States } & \multicolumn{10}{|c|}{$\mathrm{CP}_{\mathrm{K}}$} \\
\hline & \multicolumn{2}{|c|}{ Chickpea } & \multicolumn{2}{|c|}{ Pigeonpea } & \multicolumn{2}{|c|}{ Urdbean } & \multicolumn{2}{|c|}{ Mungbean } & \multicolumn{2}{|c|}{ Lentil } \\
\hline & 2001 & 2011 & 2001 & 2011 & 2001 & 2011 & 2001 & 2011 & 2001 & 2011 \\
\hline Andhra Pradesh & 6.06 & 9.11 & 9.77 & 8.46 & 32.19 & 15.44 & 18.12 & 9.24 & 0.00 & 0.00 \\
\hline Assam & 0.03 & 0.01 & 0.23 & 0.16 & 1.73 & 1.67 & 0.33 & 0.23 & 1.19 & 1.29 \\
\hline Bihar & 2.08 & 0.97 & 2.63 & 1.75 & 1.67 & 1.10 & 10.69 & 6.51 & 18.81 & 23.53 \\
\hline Gujarat & 0.24 & 2.92 & 4.78 & 8.71 & 2.04 & 4.23 & 3.76 & 5.85 & 0.00 & 0.00 \\
\hline Haryana & 2.12 & 1.38 & 0.52 & 0.86 & 0.02 & 0.06 & 0.18 & 0.72 & 0.55 & 0.28 \\
\hline Karnataka & 6.33 & 7.56 & 11.75 & 16.24 & 4.61 & 2.76 & 18.20 & 6.18 & 0.00 & 0.00 \\
\hline Madhya Pradesh & 42.87 & 33.78 & 11.75 & 16.24 & 8.73 & 14.16 & 2.24 & 1.95 & 22.98 & 19.50 \\
\hline Maharashtra & 9.29 & 16.64 & 29.45 & 31.84 & 16.91 & 19.98 & 24.02 & 21.15 & 0.22 & 0.22 \\
\hline Odisha & 0.26 & 0.39 & 3.34 & 3.92 & 2.25 & 2.45 & 2.88 & 4.40 & 0.00 & 0.00 \\
\hline Punjab & 0.19 & 0.05 & 0.34 & 0.12 & 0.14 & 0.10 & 1.81 & 0.35 & 0.34 & 0.08 \\
\hline Rajasthan & 10.49 & 20.14 & 0.43 & 0.51 & 2.68 & 5.76 & 7.81 & 36.29 & 2.87 & 4.21 \\
\hline Tamil Nadu & 0.10 & 0.08 & 2.01 & 1.21 & 10.49 & 7.78 & 5.97 & 4.01 & 0.00 & 0.00 \\
\hline Uttar Pradesh & 18.59 & 6.67 & 22.74 & 9.83 & 13.43 & 22.37 & 3.21 & 2.51 & 45.42 & 45.04 \\
\hline West Bengal & 1.33 & 0.31 & 0.26 & 0.03 & 3.02 & 2.14 & 0.64 & 0.61 & 7.62 & 5.85 \\
\hline
\end{tabular}

Source: Author's Calculation 


\section{Changing Yield of Pulses in Indian States}

Production per hectare or yield of pulses indicates the productivity level and intensity of production. Production of pulses per hectare varies across states. Highest productivity accounted by yield is observed in Rajasthan, followed by Gujarat. Five states have exhibited a decline in pulse yield over the years 2001-2011. Almost all the states except Karnataka and Tamil Nadu have experienced a rise in the yield of chickpea production in India (Table 3).

Highest productivity level is observed in Gujarat, followed by Haryana and Rajasthan. Four major states exhibit a decline in the yield of pigeonpea during the period. Gujarat reveals the highest position. In case of urdbean production per hectare, Gujarat, Haryana and Maharashtra have exhibited substantial change during the period. Rajasthan has experienced the highest increase in the yield of mungbean. A decline in the yield of lentil is observed in four states. Haryana shows highest positive change in lentil production per hectare.

\section{Yield of Pulses: Role of CII}

In order to examine the role of CII and other several factors towards better yield of pulse production in India, we have performed the regression analysis as described in the methodology section (Section II). Cross-section Regression results are depicted in Table 4. Three regression models are estimated by combining different explanatory factors as shown in column 1, column 2 and column 3 (Table 4). From the above regression estimates (Table 4), composite input index (CII), net under-ground water availability (IXNGWA) and proportion of indebted farmers in agriculture (IXIDFA) has emerged as significant factors affecting production of pulses per hectare in India. The positive and significant coefficient of composite input index (CII) implies that combined utilization of irrigation, fertilizer, manures, pesticides, and HYV seeds boost up the productivity of pulses in India. Inclusion of significant variables in model 2 and model 3 could not change the coefficient of CII as much. It ensures the most significant role of composite quality inputs towards better production pulses per hectre. The sufficient availability of ground water is also essential to raise the productivity level of pulses in India.

The increase in the proportion of indebted farmers has negative and significant effect on yield of pulses. Rural poor farmers always tend to avoid intricated credit norms, complex paper works and depositing mortgage against loans. Most of the farmers then usually dependent on credit (loan) provided by the money lenders. Hence money lenders get the opportunity to make maximum exploitation of these poor small and marginal farmers. Farmers then fall in debt trap and productivity level shrinks. Share

Table 3: Change in Yield (Kg/Ha) of Pulses during 2001-2011: Indian States

\begin{tabular}{ccccccc}
\hline States & Chickpea & Pigeonpea & Urdbean & Mungbean & Lentil & All Pulses \\
\hline Andhra Pradesh & 96.00 & -12.00 & -156.00 & 85.00 & 0.00 & 36.5 \\
Assam & 19.00 & 6.00 & 19.00 & -1.00 & -33.00 & 12.52 \\
Bihar & 149.00 & 167.00 & 218.00 & 88.00 & -81.00 & -10.42 \\
Gujarat & 643.00 & 649.00 & 382.00 & 249.00 & 0.00 & 277.56 \\
Haryana & 342.00 & 312.00 & 333.00 & 336.00 & 126.00 & 85.11 \\
Karnataka & -22.00 & 119.00 & -32.00 & 91.00 & 0.00 & 56.56 \\
Madhya Pradesh & 44.00 & 119.00 & 138.00 & 100.00 & -121.00 & 49.03 \\
Maharashtra & 411.00 & 154.00 & 315.00 & 314.00 & 167.00 & 92.13 \\
Orissa & 273.00 & 406.00 & 47.00 & 94.00 & 0.00 & 94.64 \\
Punjab & 278.00 & 55.00 & 85.00 & 184.00 & -24.00 & -45.95 \\
Rajasthan & 308.00 & 380.00 & 449.00 & 448.00 & -317.00 & 339.64 \\
Tamil Nadu & -23.00 & -83.00 & -64.00 & -108.00 & 0.00 & -5.34 \\
Uttar Pradesh & 86.00 & -359.00 & 245.00 & 177.00 & 75.00 & -6.86 \\
West Bengal & 188.00 & -20.00 & 137.00 & 52.00 & 28.00 & -26.58 \\
\hline
\end{tabular}

Source: Author's Calculation 
Table 4: Factors affecting Pulse Production in India: Regression Estimates

\begin{tabular}{cccc}
\hline Factors & Model 1 & Model 2 & Model 2 \\
\hline CII & $0.720^{* *}(0.047)$ & $0.685^{* * *}(0.004)$ & $0.682^{* *}(0.013)$ \\
IXIDFA & $-0.541^{* *}(0.0 .39)$ & $-0.570^{* * *}(0.002)$ & $-0.572^{* * *}(0.005)$ \\
IXNGWA & & $0.625^{* * *}(0.001)$ & $0.626^{* * *}(0.002)$ \\
IXECA & & & $0.003(0.979)$ \\
$C$ & $6.464(0.000)$ & $6.306^{* * *}(0.000)$ & $6.305^{* * *}(0.000)$ \\
$R^{\wedge} 2$ & 0.47 & 0.85 & 0.85 \\
Adjusted $R^{\wedge} 2$ & 0.37 & 0.80 & 0.77 \\
F-Value & $4.48(0.040)$ & $16.54(0.001)$ & $11.03(0.002)$ \\
\hline
\end{tabular}

***Significant at 1 percent level; **Significant at 5 percent level; *Significant at 10 percent level

of electricity consumption in agriculture also have positive impact on yield of pulses (Model 3).

\section{CONCLUSION}

The pulse production in India is concentrated in the states of Madhya Pradesh, Karnataka, Maharashtra, Uttar Pradesh and Rajasthan. Rajasthan has experienced highest increase in the production of pulses during the period. Madhya Pradesh is emerged as the highest contributor to overall Chickpea production in India. Maximum contribution to Pigeonpea production is observed in Maharashtra. Gujarat shows the highest increase in the yield of Chickpea and Pigeonpea. Composite quality inputs, net under-ground water availability, and proportion of indebted farmers in agriculture have emerged as significant factors influencing pulse productivity. Composite quality input index (CII) significantly affect per hectare pulse production in India. Moreover, number of indebted farmers has negative and significant impact on productivity of pulses.

As composition of quality inputs (irrigation, pesticides, fertilizers, HYV seeds, etc) significantly enhances productivity level of pulses, Govt. should take initiative to make these inputs combination available to the rural farmers at a very low cost. Government may adopt the policy of distribution system (like PDS) where farmers can get quality inputs for cultivation at low cost. Major causes of indebtedness of agricultural farmers lies behind the failure of institutional credit, increasing cost of agricultural inputs, low prices for agricultural products, rising dependence on moneylenders for loans provided at high interest rates and crop failure due to unsuitable climatic conditions (Shiva and Jalees, 2009). Hence, Government should take initiatives to promote debt waiver scheme for the farmers, to provide enough subsidies for procurement of agricultural resources, to provide adequate crop insurance facilities, and to regulate the minimum support price of pulses. Major role should be taken on the part of the Government to boost up the production of pulses in India to meet the huge domestic demand and to bring about price stability so that poor Indian at least can take cereals and pulses together in their meals.

\section{REFERENCES}

Ali, M. and Gupta, S. 2012. Carrying capacity of Indian agriculture: pulse crops. Current Science, 102(6).

Joshi, P.K. and Saxena, R. 2002. A profile of pulses production in India: Facts, trends and opportunities. Indian Journal of Agricultural Economics, 57(3): 326- 339.

Kumar P. 1998. Food Demand and Supply Projections for India. Agricultural Economics Policy. Paper 98-01. New Delhi: Indian Agricultural Research Institute, New Delhi.

Kumar, S. and Bourai, V.A. 2012. Economic Analysis of Pulses Production, their Economic Benefits and Constraints" (A Case Study of Sample Villages of Assan Valley of Uttarakhand, India. IOSR Journal of Humanities and Social Sciences, 1(4): 41-53.

Mittal, S. 2006. Structural shift in demand for food: projections to 2020. Working Paper No. 184. New Delhi: Indian Council for Research on International Economic Relations.

Narayan, P. and Kumar, S. 2015. Constraints of growth in production and productivity of pulses in India: An analytical approach to major pulses. Indian Journal of Agriculture Research, 49(2): 114-124.

RoyBurman, R., Singh, S.K., Singh, L. and Singh, A.K. 2008. Extension Strategies for Increasing Pulse Production for Evergreen Revolution. Indian Research Journal Ext. Edu., $8(1)$. 
Reddy, A.A. 2009. Policy Options for India's Edible Oil Complex. Economic and Political Weekly, 44(4): 22-24.

Reddy, A.A. and Reddy, G.P. 2010. Supply Side Constrains in Production of Pulses in India: A Case Study of Lentil. Agricultural Economics Research Review, 23: 129-136.

Srivastava, S.K. and Mathur, V.C. 2011. Spatial and temporal consumption and production pattern of pulses in India. Pusa AgriScience, 34: 79-86.

Shiva, V. and Jalees, K. 2009. Farmers Suicide in India. Research Foundation for Science, Technology and Ecology, the University of Michigan.
Singh, K.M., Chaudhary, J.N. and Singh, R.K.P. 1993. An Analysis of Compound Growth Rates and Factors Affecting Area, Production and Productivity of Gram in Bihar. Agricultural Situation in India, pp. 841-846.

Singh, A.K., Manibhushan, Bhatt, B.P., Singh, K.M. and Upadhyaya, A. 2013. An Analysis of Oilseeds and Pulses Scenario in Eastern India during 2050-51. Journal of Agricultural Science, 5(1): 241-249. 
